\title{
Occurrence of Vibrio, Salmonella and Staphylococcus aureus in retail fresh fish, mussel and shrimp
}

\author{
Tulay Elal Mus, Figen Cetinkaya, Umut Celik
}

University of Uludag, Faculty of Veterinary Medicine, Department of Food Hygiene and Technology, Bursa, Turkey

Received June 12, 2013

Accepted March 26, 2014

\begin{abstract}
This study aimed to determine the presence of pathogenic Vibrio spp., S. aureus and Salmonella in 100 seafood samples purchased from retail outlets in Bursa city (Turkey). Of the samples examined including fish, mussel and shrimp, 67\% were found to be contaminated with Vibrio. Presumed Vibrio spp. were identified by standard biochemical tests, and further confirmed by API 20E system. Identified Vibrio spp. were $V$. parahaemolyticus $(28 \%), V$. vulnificus $(1 \%)$ and $V$. cholerae (1\%), with the most prevalent being $V$. alginolyticus $(37 \%)$. Six $(6 \%)$ of the samples analysed were positive for $S$. aureus. However, no contamination of the samples with Salmonella was observed. Our results showed that seafood from retail outlets can be a likely vehicle for infections with Vibrio spp. and $S$. aureus.
\end{abstract}

Seafood, pathogen bacteria, incidence, microbiological quality

In addition to being a healthy food with nutritional value, seafood can also act as a source of foodborne pathogens (Hudecová et al. 2010; Bakr et al. 2011). Various outbreaks of bacterial disease associated with the consumption of seafood have been reported (Guerin et al. 2004; Friesema et al. 2012). From these seafood-borne bacteria, Vibrio spp. are Gram-negative rod-shaped and halophilic bacteria that generally widespread in the coastal and estuarine environments (Austin 2010). Among more than 20 Vibrio species known to be associated with human disease, $V$. cholerae, $V$. parahaemolyticus and $V$. vulnificus are the pathogenic species of Vibrio that pose the greatest threat to human health (Gopal et al. 2005; Cariani et al. 2012).

Salmonella and $S$. aureus are the leading foodborne pathogens, causative agents of the most common enteric infections to humans (Lei et al. 2008; Kumar et al. 2009). These bacteria can enter the aquatic environment through wild animals, domestic stock, poor sanitation and inappropriate disposal of human and animal wastes (Amagliani et al. 2012). Various authors have reported the incidence of Salmonella (Woodring et al. 2012) and enterotoxigenic $S$. aureus (Popovic et al. 2010) in seafood.

In this study, we investigated the prevalence of pathogenic Vibrio spp., Salmonella and $S$. aureus contamination in fish, mussel and shrimp from the retail level in order to assess health risks for consumers, and also determined the identification to species level of the Vibrio strains isolated from samples.

\section{Materials and Methods}

Sample collection

During 2012, a total of 100 fresh seafood samples including 78 fish, 12 mussel and 10 shrimp were collected from several supermarkets, fish markets and neighbourhood bazaars in Bursa province, Turkey. The samples were placed into sterile bags and transported to the laboratory under refrigerated conditions for analysis.

Isolation and identification

The detection of pathogenic Vibrio species was achieved according to the standard methods of the U.S. Food and Drug Administration (FDA) (DePaola and Kaysner 2004). Approximately $25 \mathrm{~g}$ of each sample were

Address for correspondence:

Figen Cetinkaya

Department of Food Hygiene and Technology

Faculty of Veterinary Medicine, University of Uludag

16059 Gorukle Campus, Bursa, Turkey
Phone: +90224294 1212

Fax: +90224294 1202

E-mail: figcetinkaya@yahoo.com

http://actavet.vfu.cz/ 
homogenized in $225 \mathrm{ml}$ Alkaline Peptone Water (APW) (Merck 1.01800) with $2 \% \mathrm{NaCl}$ and incubated overnight at $35 \pm 2{ }^{\circ} \mathrm{C}$. A loop of the pre-enriched culture was streaked onto Thiosulphate Citrate Bile Salts Sucrose (TCBS) agar (Merck 1.10263). After incubation at $35 \pm 2{ }^{\circ} \mathrm{C}$ for $18-24 \mathrm{~h}$, presumptive colonies were firstly characterized by biochemical tests which included Gram staining, motility, oxidase production, 0129 vibriostat susceptibility (Oxoid DD0015), and then identified at the genus and species level using API 20E (BioMerieux, France) test kits.

For the isolation of Salmonella, $25 \mathrm{~g}$ of seafood samples were homogenized in $225 \mathrm{ml}$ of Buffered Peptone Water (Oxoid CM0509) and then incubated at $37{ }^{\circ} \mathrm{C}$ for $16-20 \mathrm{~h} .0 .1 \mathrm{ml}$ of the pre-enrichment culture was inoculated into tubes containing $10 \mathrm{ml}$ Rappaport Vassiliadis medium (Oxoid CM0669) and incubated $24 \mathrm{~h}$ at $42{ }^{\circ} \mathrm{C}$. A loopful from each tube was streaked on Xylose Lactose Tergitol 4 agar (XLT4) (Merck 1.13919). After incubation at $37^{\circ} \mathrm{C}$ for $20-24 \mathrm{~h}$, presumptive Salmonella colonies were subjected to initial screening tests using triple sugar iron agar (Oxoid CM0277), lysine iron agar (Oxoid CM0381), urea broth (Oxoid CM0071) and lysine decarboxylase broth (Oxoid CM308). Presumptive positive results were confirmed by Poly O (Denka Seiken, Tokyo, Japan) and Poly H slide agglutination tests (Andrews and Hammack 1998).

For the detection of $S$. aureus, $10 \mathrm{~g}$ seafood samples were homogenized with $90 \mathrm{ml}$ of a sterile $0.1 \%$ peptone water solution. Serial dilutions of the homogenate were made with sterile peptone water and plated in duplicates on Baird Parker agar (Merck 1.05406) supplemented with egg yolk-tellurite emulsion (Merck 1.03785). After incubation at $35^{\circ} \mathrm{C}$ for $48 \mathrm{~h}$, the typical black with clear halo colonies of $S$. aureus were tested for coagulase activity using Dry Spot Staphytect Plus (Oxoid DR0100) (Harrigan 1998).

\section{Results}

This study was conducted to determine the incidence of Vibrio spp., S. aureus and Salmonella spp. in seafood (78 fish, 12 mussel and 10 shrimp) for sale in retail outlets. The results related to the incidence and identification at the species level of Vibrio spp. are summarized in Table 1. Sixty-seven (67\%) out of 100 samples were found to be contaminated with Vibrio spp. The isolates were identified as $V$. vulnificus (one isolate), $V$. cholerae (one isolate), V. parahaemolyticus (28 isolates) and V. alginolyticus (37 isolates) using API 20E system. V. vulnificus was isolated from one fish sample while $V$. cholerae was detected in one shrimp sample. Among $28 \mathrm{~V}$. parahaemolyticus isolates, 25 were found in fish samples and three in mussels. As seen in Table 2, $6(6 \%)$ from 100 seafood samples were contaminated with $S$. aureus. Salmonella was not detected in the samples analysed in this study.

\section{Discussion}

Vibrio spp. was isolated in $67 \%$ of total count of the samples. By API 20E system, the isolates were identified as $V$. vulnificus, V. cholerae, V.parahaemolyticus and V. alginolyticus. The total rate of isolation of $V$. parahaemolyticus in the samples analysed was $28 \%$ (Table 1 ). In comparison to the results of our study, previous studies with seafood from several

Table 1. Incidence and species distribution of Vibrio spp. from seafood.

\begin{tabular}{|c|c|c|c|c|}
\hline \multirow{2}{*}{ Sample type } & \multirow{2}{*}{ No. of samples } & \multirow{2}{*}{$\begin{array}{l}\text { No. of positive } \\
\text { samples (\%) }\end{array}$} & \multicolumn{2}{|c|}{ Vibrio isolated } \\
\hline & & & No. & Species \\
\hline \multirow[t]{3}{*}{ Fish } & 78 & $53(67.9)$ & 1 & V. vulnificus \\
\hline & & & 25 & V. parahaemolyticus \\
\hline & & & 27 & V. alginolyticus \\
\hline \multirow[t]{2}{*}{ Mussel } & 12 & $9(75)$ & 3 & V. parahaemolyticus \\
\hline & & & 6 & V. alginolyticus \\
\hline \multirow[t]{2}{*}{ Shrimp } & 10 & $5(50)$ & 1 & V. cholerae \\
\hline & & & 4 & V. alginolyticus \\
\hline Total & 100 & $67(67)$ & & \\
\hline
\end{tabular}


Table 2. Incidence of S. aureus and Salmonella in seafood.

\begin{tabular}{lcccc}
\hline Sample type & No. of samples & $\begin{array}{c}\text { No. of samples } \\
\text { with S. aureus }\end{array}$ & $\begin{array}{c}\% \text { of } \\
\text { incidence }\end{array}$ & $\begin{array}{c}\text { No. of samples } \\
\text { with Salmonella }\end{array}$ \\
\hline Fish & 78 & 3 & 3.8 & 0 \\
Mussel & 12 & 1 & 8.3 & 0 \\
Shrimp & 10 & 2 & 20 & 0 \\
Total & 100 & 6 & 6.0 & 0 \\
\hline
\end{tabular}

countries demonstrated higher prevalence of $V$. parahaemolyticus. In a study on seafood products in China (Chao et al. 2009), the incidence of this bacterium was found to be $56.6 \%$. The rates of $V$. parahaemolyticus contamination of seafood by Chakraborty et al. (2008) in India and by Costa Sobrinho et al. (2011) in Brazil were reported as 64\% and $100 \%$, respectively. However, the incidence $(28 \%)$ of $V$. parahaemolyticus in retail seafood reported here was relatively higher than that reported by Baffone et al. (2000) (14.8\%) and by Ottaviani et al. (2005) (24.3\%).

The single isolate of $V$. vulnificus in our study originated from fish. Canigral et al. (2010) also reported that this bacterium was recovered from two oyster samples in Spain. Studies conducted by $\mathrm{Ji}$ et al. (2011) suggested that 140 out of 239 shrimp samples from Chinese seafood markets were contaminated with $V$. vulnificus. Vibrio cholerae, the causative agent of cholera in humans, was detected in only one shrimp sample (1\%). Higher incidence rate $(3.7 \%)$ of $V$. cholerae in seafood products was suggested in a study conducted by Baffone et al. (2000). On the other hand, $V$. cholerae was not isolated from any of the shrimp samples investigated by Hosseini et al. (2004).

Although $V$. parahaemolyticus, $V$. cholerae and $V$. vulnificus are the main species associated with seafood-borne infections, others including $V$. alginolyticus, $V$. mimicus and Grimontia hollisae (formerly $V$. hollisae) have been sporadically found in outbreaks (Cariani et al. 2012). In this study, V. alginolyticus was detected in 27 fish, 6 mussel and 4 shrimp samples, with a total incidence rate of $37 \%$. In a study on fish, mussels and clams in Italy (Baffone et al. 2000), 81.5\% of the samples were positive for $V$. alginolyticus. In India, an investigation showed that $V$. alginolyticus was present in $19 \%$ of 30 west coast shrimp samples analysed (Gopal et al. 2005).

Our study revealed that of 100 seafood products, six (6\%) samples harboured S. aureus. Three isolates of $S$. aureus were obtained from fish samples, one isolate from mussels and two isolates from shrimp (Table 2). Five of the isolates were found to be coagulase positive except for one isolate from mussels. Much higher incidence rates of $S$. aureus were reported for fresh (43\%) and frozen (30\%) fishery products in Spain (Vazquez-Sanchez et al. 2012), and for low salt sardine (86.7\%), feseikh (93.3\%) and molouha (90\%) fish samples in Egypt (Ezzeldeen et al. 2011).

Salmonella was not detected in the samples analysed in this study, which was in agreement with previous studies (Popovic et al. 2010; Rodriguez et al. 2011) in seafood products. Conversely, different workers (Shabarinath et al. 2007; Kumar et al. 2009; Bakr et al. 2011) reported varying incidence rates of Salmonella in seafood.

In summary, this work revealed the presence of potentially pathogenic bacteria in seafood including fish, mussel and shrimp, and a probable health risk for consumers of raw seafood. The data presented here are useful for risk assessment and management of pathogenic Vibrio spp. and S. aureus in seafood. Improvement of the effective sanitary conditions in handling and processing operations from fishing to marketing is needed to minimize the risk of infections associated with consumption of these products. 


\section{References}

Amagliani G, Brandi G, Schiavano GF 2012: Incidence and role of Salmonella in seafood safety. Food Res Int 45: $780-788$

Andrews WH, Hammack TS 1998: Salmonella. In: Food and Drug Administration, Bacteriological Analytical Manual. $8^{\text {th }}$ Edition (Revision A), AOAC International, Gaithersburg, MD

Austin B 2010: Vibrios as causal agents of zoonoses. Vet Microbiol 140: 310-317

Baffone W, Pianetti A, Bruscolini F, Barbieri E, Citterio B 2000: Occurence and expression of virulence-related properties of Vibrio species isolated from widely consumed seafood products. Int J Food Microbiol 54: 9-18

Bakr WMK, Hazzah WA, Abaza AF 2011: Detection of Salmonella and Vibrio species in some seafood in Alexandria. J Am Sci 7: 663-668

Canigral I, Moreno Y, Alonso JL, Gonzales A, Ferrus MA 2010: Detection of Vibrio vulnificus in seafood, seawater and waste water samples from a Mediterranean coastal area. Microbiol Res 165: 657-664.

Cariani A, Piano A, Consolandi C, Severgnini M, Castiglioni B, Caredda G, Candela M, Serratore P, De Bellis G, Tinti F 2012: Detection and characterization of pathogenic vibrios in shellfish by a ligation detection reactionuniversal array approach. Int J Food Microbiol 153: 474-482

Chakraborty RD, Surendran PK, Joseph TC 2008: Isolation and characterization of Vibrio parahaemolyticus from seafoods along the southwest coast of India. World J Microb Biot 24: 2045-2054

Chao G, Jiao X, Zhou X, Yang Z, Huang J, Zhou L, Qian X 2009: Distribution, prevalence, molecular typing, and virulence of Vibrio parahaemolyticus isolated from different sources in coastal province Jiangsu, China. Food Control 20: 907-912

Costa Sobrinho PS, Destro MT, Franco BDGM, Landgraf M 2011: Occurence and distribution of Vibrio parahaemolyticus in retail oysters in Sao Paulo State, Brazil. Food Microbiol 28: 137-140

DePaola A, Kaysner CA 2004: Vibrio, Chapter 9. In: Food and Drug Administration, Bacteriological Analytical Manual. $8^{\text {th }}$ Edition (Revision A), 1998, Washington, DC.

Ezzeldeen NA, Mansour HA, Ahmed AA 2011: Phenotypic and molecular identification of Staphylococcus aureus isolated from some Egyptian salted fish. World Appl Sci J 15: 1703-1712

Friesema IH, De Jong AE, Fitz James IA, Heck ME, van den Kerkhof JH, Notermans DW 2012. Outbreak of Salmonella Thompson in the Netherlands since July 2012. Euro Surveill 17: 1-4

Gopal S, Otta SK, Kumar S, Karunasagar I, Nishibuchi M, Karunasagar I 2005: The occurence of Vibrio species in tropical shrimp culture environments, implications for food safety. Int J Food Microbiol 102: 151-159

Guerin PJ, De Jong B, Heir E, Hasseltvedt V, Kapperud G, Styrmo K, Gondrosen B, Lassen J, Andersson Y, Aavitsland P 2004: Outbreak of Salmonella Livingstone infection in Norway and Sweden due to contaminated processed fish products. Epidemiol Infect 132: 889-895

Harrigan WF 1998: Laboratory Methods in Food Microbiology. $3^{\text {rd }}$ edn, Academic Press, London

Hosseini H, Cheraghali AM, Yalfani R, Razavilar V 2004: Incidence of Vibrio spp. in shrimp caught off the South coast of Iran. Food Control 15: 187-190

Hudecová K, Buchtová H, Steinhauserová I 2010: The effects of modified atmosphere packaging on the microbiological properties of fresh common carp (Cyprinus carpio L.). Acta Vet Brno 79: 93-100

Ji H, Chen Y, Guo Y, Liu X, Wen J, Liu H 2011: Occurence and characteristics of Vibrio vulnificus in retail marine shrimp in China. Food Control 22: 1935-1940

Kumar R, Surendran PK, Thampuran N 2009: Distribution and genotypic characterization of Salmonella serovars isolated from tropical seafood of Cochin, India. J Appl Microbiol 106: 515-524

Lei IF, Roffey P, Blanchard C, Gu K 2008: Development of a multiplex PCR method for the detection of six common foodborne pathogens. J Food Drug Anal 16: 37-43

Ottaviani D, Santarelli S, Bacchiocchi S, Masini L, Ghittino C, Bacchiocchi I 2005: Presence of pathogenic Vibrio parahaemolyticus strains in mussels from the Adriatic Sea, Italy. Food Microbiol 22: 585-590

Popovic NT, Skukan AB, Dzidara P, Coz-Rakovac R, Strunjak-Perovic I, Kozacinski L, Jadan M, Brlek-Gorski D 2010: Microbiological quality of marketed fresh and frozen seafood caught of the Adriatic coast of Croatia. Vet Med 55: 233-241

Rodriguez AI, Hariharan H, Nimrod S 2011: Occurence and antimicrobial drug resistance of potential bacterial pathogens from shellfish, including queen conchs (Strombus gigas) and whelks (Cittarium pica) in Grenada. Webmedcentral Microbiol 2: WMC001943

Shabarinath S, Kumar HS, Khushiramani R, Karunasagar I, Karunasagar I 2007: Detection and characterization of Salmonella associated with tropical seafood. Int J Food Microbiol 114: 227-233

Vazquez-Sanchez D, Lopez-Cabo M, Saa-Ibusquiza P, Rodriguez-Herrera JJ 2012: Incidence and characterization of Staphylococcus aureus in fishery products marketed in Galicia (Northwest Spain). Int J Food Microbiol 157: 286-296

Woodring J, Srijan A, Puripunyakom P, Oransathid W, Wongstitwilairoong B, Mason C 2012: Prevalence and antimicrobial susceptibilities of Vibrio, Salmonella and Aeromonas isolates from various uncooked seafoods in Thailand. J Food Protect 75: 41-47 